"An investigation of entrepreneurial skills for contingent employees in small retail businesses as job security determinants"

\begin{tabular}{ll} 
AUTHORS & $\begin{array}{l}\text { Germinah Evelyn Chiloane-Tsoka } \\
\text { Bheki Tshabangu }\end{array}$ \\
& $\begin{array}{l}\text { Germinah Evelyn Chiloane-Tsoka and Bheki Tshabangu (2016). An } \\
\text { investigation of entrepreneurial skills for contingent employees in small retail } \\
\text { businesses as job security determinants. Problems and Perspectives in } \\
\text { Management, 14(3-3), 642-649. doi:10.21511/ppm.14(3-3).2016.07 }\end{array}$ \\
\hline ARTICLE INFO & http://dx.doi.org/10.21511/ppm.14(3-3).2016.07 \\
\hline DOI & Thursday, 10 November 2016 \\
\hline RELEASED ON & "Problems and Perspectives in Management" \\
\hline JOURNAL & LLC "Consulting Publishing Company "Business Perspectives" \\
\hline FOUNDER &
\end{tabular}

NUMBER OF REFERENCES

0
NUMBER OF FIGURES

0

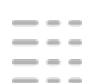

NUMBER OF TABLES

0

(C) The author(s) 2023. This publication is an open access article. 
Germinah Evelyn Chiloane-Tsoka (South Africa), Bheki Tshabangu (South Africa)

\title{
An investigation of entrepreneurial skills for contingent employees in small retail businesses as job security determinants
}

\begin{abstract}
SMEs provide employment to approximately 61 per cent of households in South Africa (SA). Though, entrepreneurial activity rate (TEA) still poses a great concern, at 5.9\% which is far below that of the BRICS (Brazil, Russia, India, China). Contingent employees in small retail businesses continue to face job insecurity as a result of poor working conditions and ununionized. This study aims to explore whether contingent employees have entrepreneurial skills for self-employability as an opportunity to offset job insecurity in Roodepoort, SA. Likewise, the study used a quantitative approach and sampled 129 contingent employees from 60 small retail businesses in Roodepoort. Findings revealed that there is a significant relationship between entrepreneurial skills, job insecurity and contingent employees regarding job insecurity.
\end{abstract}

Keywords: contingent employees, SME, job insecurity, unions, entrepreneurial skills, Roodepoort and South Africa. JEL Classification: J46, L26.

\section{Introduction}

Freelance statistic (2015) indicates that the freelance workforce is powerful and growing at a fast pace. It is anticipated that by 2020 , more than $40 \%$ of the US workforce will be so-called contingent workers. Those who are temporary employees and hired to assist employers to meet business demands, yet, allow the employer to avoid the cost of hiring a regular employee (Heathfield, 2016). Nonetheless, the South African workforce has been faced with various challenges since the revised labor laws in the early 1990s, that resulted in an increased use of contingent employees and diminishing prospects of permanent employment (Leibbrandt, Woolard, McEwen \& Koep, 2008, p. 14; Dachapalli \& Parumasur, 2012, p. 31). The Labor Relations Act No. 66 of 1995, Skill Development Act No. 97 of 1998, Basic Conditions of Employment Act No. 75 of 1997, and the Employment Equity Act No. 55 of 1998 were passed into law with intentions to enhance labor peace and preserving employees' rights and human dignity. Fourie (2008, p. 111) expressed disenchantment on the limitations of the South African labor laws that, in his view, seemed to only have safeguard the permanent employees' environment, while lacking the efficiency to advance the rights of contingent employees. As a result of this phenomenon, there has been an unprecedented increase in contingent employment, as opposed to permanent employees.

Part-time-employment as opposed to permanent job security, resulted in identification of the gap of entrepreneurship skills for contingent employees as a fundamental base to self-employment rather than contingent job insecurity. In a study conducted by Bhandari and Heshmati (2006, p. 3), they assert that job insecurity remains a matter of grave concern,

(C) Germinah Evelyn Chiloane-Tsoka, Bheki Tshabangu, 2016. Germinah Evelyn Chiloane-Tsoka, Ph.D., Professor, Faculty of Economic and Management Sciences, School of Applied Sciences, University of South Africa, South Africa.

Bheki Tshabangu, SRM Project Manager, University of South Africa, South Africa. and presents an opportunity for closer investigation and debate around the factors that may exacerbate entrepreneurial conversation and activity. A compelling argument advanced by Fourie (2008, p. 112) is that most contingent employees are poorly educated, unskilled and have no access to collective bargaining coverage leaving them exposed to job insecurity, as compared to full-time employees. Furthermore, GEM (2012, p. 7) report revealed that gender disparities are also a key role determinants in contingent employment. Ethnicity also plays a an important contribution as higher rate of contingent jobs are held by African, 81.4 per cent compared to 10.1 percent Coloured, Asians, 3.9 per cent and White, 4.7 per cent. There are no proper evidence provided why Asians are few operating as contingent workers. This could have added more value in understanding perceptions from different ethnic groups pertaining contingent workforce.

In a study conducted by Dachapalli and Parumasur (2012, p. 31), it is established that there are other factors which encouraged contingent employment that emanated as the result of the global economic downturn. These were factors such as the volatile situation in Europe, United States of America and the Middle East, outsourcing certain functions of business and new advances in information technology. This view was propelled by the proven difficulties of businesses to accelerate growth, whilst the world economy was seen to be in shambles. Dachapalli and Parumasur (2012, p. 31) emphasized that the consequences were embedded by companies and, as such, they had to minimize production costs in order to survive.

Due to the above background of contingent employees, some scholars contributed to the body of knowledge on the understanding of what contingent employment. Thus, McGuinness, Woolen \& Hahn (2012, p. 1), Bhandari, \& Heshmati (2006, p. 3), Meltzer, Bebbington, Brugha, Jenkins, McManus \& Stansfeld (2010, p. 1401) have offered varying definitions for job insecurity. In their view, the 
concept is built towards the underlying factor as a sense of powerlessness or fear for job loss by an employee. Given the perspective of what job insecurity is, the scholars' contribution provided a platform for entrepreneurial skills as another intervention within the entrepreneur's support system that involves identifying and analyzing potential entrepreneurs' creativity and innovation, sources of business finance, marketing skills, financial and accounting skills and other relevant skills. Therefore, in this paper, the objectives are:

- to investigate whether contingent employees have the necessary entrepreneurial skills to start their own business as a job security determinant and entrepreneurial factor;

- to investigate whether contingent employees have entrepreneurial skills in Roodepoort, SA.

The research question was formulated to answer whether contingent employees have entrepreneurial skills in small retail businesses of Roodepoort, SA. Two hypothetical statements were formulated to further investigate the problem:

$\mathrm{H}_{0}$ : Job insecurity is not associated with nature of organization.

$\mathrm{H}_{1}$ : Job insecurity is associated with nature of organization.

\section{Research problem}

In South Africa, 91 per cent of formal small businesses contribute between 52-57 per cent to GDP and 61 per cent to employment (Abor and Quartey, 2010, p. 218). Small business is regarded as engine of growth, as a result, small business sector in South Africa's boasts employment rate and contributes positively to GDP. However, small business is largely affected by restrained resources, such as, capital, land, materials, technology and entrepreneurship, which render the sector as unsustainable and escalate preference to contingent employment. Adcorp (2014) reports on Employment Index established that there was 54,184 decline in permanent employment and increase of 27,250 contingent employment in 2014. While contingent jobs offer low earnings, poor working conditions, redundancy, discrimination, minimal representation by unions and job dissatisfaction which culminate into job insecurity. Therefore, entrepreneurial skills are seen as a beacon of hope for the job loss and a pull-factor to job insecurity that often drive employees to entrepreneurship (Verheul, Thurik Hessels \& van der Zwan, 2010, p. 5).

\section{Research methodology}

Cooper and Schindler (2014, p. 82) define research design as a technique method or a plan of steps undertaken to respond to the study problem and objectives. In this study, a quantitative approach was followed using a descriptive survey. The targeted population comprised of contingent employees from small retail businesses in Roodepoort, Gauteng. Roodepoort is located in the western part of Johannesburg in the Gauteng Province of South Africa. The population of Roodepoort is estimated at approximately 225000 (Mongabay.com, 2012). According to the Roodepoort Information and Chamber of Commerce \& Industry, 503 small businesses are available on their database. The composition of SMEs comprised of beauty apparel shops, liquor stores, restaurants \& food outlets, filling stations, general dealers and clothing stores. The approach was applied to offset possible overestimation or underestimation of the population.

Probability sampling was suitable for the study given that the target participants were contingent employees and no modifications were permitted. According to the Roodepoort Information and Chamber of Commerce \& Industry, 503 small businesses are available on their database. Questionnaires were personally distributed to 60 small retail businesses. A quota of 10 per cent contingent employees per small retail business was administered due to survey cost implication. Furthermore, a five point Likert rating scale where one (1) indicates strongly agree and five (5) indicates strongly disagree was used to measure variables.

Other related rating scales such as "very certain and very uncertain", "very likely and very unlikely" and no "understanding and full understanding" were used to test variables. A Likert scale provides a volume of data and was easier and quicker to construct. The main advantage of the scale was to add each respondent's score and secure the total score. In this case, the aim was to control the score of the responses from contingent employees when presenting questions to participants. Prior to questionnaire administration, it was critical to explain matters of ethical considerations, the researcher provided a covering letter and the research which was bearing the University of South Africa ethics approval certificate to collect data explaining the nature of the research project, providing the assurance that the privacy of the participants in the small retail businesses in the Roodepoort District was protected, and matters of anonymity and confidentiality would be promoted and maintained (Cooper and Schindler, 2006, p. 709). Once this was done, a structured questionnaire was administered to collect data. Closed-ended questions were used to address required objectives in order to make statistical inferences about the characteristics of the contingent employees.

SPSS software was used in order to describe and analyze sets of quantitative data with regard to contingent employees. Data were edited and captured 
for processing, with the provision of descriptive measures aimed at describing data in terms of structure. Data were also summarized for each variable in the form of frequency tables. To enhance reliability in this study, the instruments were administered consistently so that there was a standardization in the use of the instrument from one respondent to the other amongst contingent employees (Zikmund, Babin, Carr \& Griffin, 2010, p. 304). While ensuring validity was measured properly, by ensuring that the instrument used measured what it was supposed to measure to avoid biasness.

\section{Literature review}

Literature review serves various purposes dependent on the nature of the study. According to Machi \& McEvoy (2012, p. 2), alluding that literature aims to explore current position about state of knowledge on the subject, whilst advanced literature reviews purport to reveal a problem statement. According to Hofstee (2006, p. 91), literature review enables the researcher to gain full understanding and confirm the theoretical base of the study in pursued exist. According to Hartog, Van Praag and Van Der Sluis (2010, p. 949), entrepreneurial skills entail cognitive and noncognitive skills applicable in order to participate to the economy and labor market. Entrepreneurial skills contribute toward effective entrepreneurship and "intrapreneurship". The literature review will discuss contingent employees. Various researchers (Sparks, Faragher \& Cooper, 2001, p. 490; Zeytinoglu, Denton, Davies \& Plenderleith, 2009, p. 259; Leibbrandt, Woolard, McEwen and Koep, 2008, p. 14) conform that contingent jobs consist of part-time or casuals, temps, non-permanent, involuntary hours, on call contract, seasonal or cyclical employees, fixed-term contract and agency employees employed.

3.1. Push-pull theory of entrepreneurship. Prior to starting and running a successful enterprise, people are motivated by several factors. The push-pull theory provides an insight of different categories for entrepreneurship and some of the factors include job insecurity and entrepreneurial skills (Nieman \& Neuwenhoud, 2015, p. 37). The impact of job insecurity to contingent employees results in poor health and job dissatisfaction. Discontentment or poor health which stem from annoying work environment should push affected individuals to new venture or career. On the same token, individuals earning low and without benefits, opt for career change which proposes better options (Ali Shah, Fakhr, Ahmad, Zaman, 2010, p. 171). Push factors (also known compelling factors) refer to attributes that drive employees towards quitting their job. Whereas pull factors (also known as ambitious factors) relate to ideals that attract employees towards new adventures, pull driving categories include job security, high salary, career advancement, new challenge, job security, better culture and climate, more freedom/autonomy, good by reputation, good boss and/or own boss are justified several scholars (Ali Shah, Fakhr, Ahmad and Zaman, 2010, pp. 179-182; Kirkword, 2009, p. 352; Islam, 2012, pp. 68-69; Dawson \& Henley, 2012, p. 705), while push factors job insecurity, economic crisis, children, unemployment rates, low wages and salaries, and no learning and developmental opportunities (Kirkwoord, 2009, p. 352, Giacomin, Guyot, Janssen \& Lohest, 2006, p. 11, Dawson \& Henley, 2012, pp. 705-707). Nonetheless job security leads to job satisfaction and loyalty. Job security success factors are dependent on number of individual, job, labor market, labor laws, economic condition, capital, technological savvy, innovation, entrepreneurial skills variables, etc. (Clark and Postel-Vinay, 2005, p. 9). Employees who experience job security feel job satisfied and protected, while the opposite is job insecurity. As a remedy for job insecurity, contingent employees are expected to opt for alternatives, and the obvious one is entrepreneurship. The consequences of job insecurity and the characteristics of contingent employees in small retail businesses are explored in this context. Firstly, job security and job insecurity measurements are discussed below.

3.2. Determinants of job insecurity. Job insecurity determinants are "variables of diverse nature in a process for generating job insecurity" (de Bustillo \& de Pedraza, 2007, p. 8; Bhandari \& Heshmati, 2006, pp. 11-13; Broom, Souza, Strazdins, Butterworth, Parslow \& Rodgers, 2006, p. 578).

For the components of job insecurity, see Table 1.

Table 1 . Job insecurity determinants

\begin{tabular}{|l|l|}
\hline \multicolumn{1}{|c|}{ Components } & \multicolumn{1}{c|}{ Subcomponents } \\
\hline \multirow{5}{*}{ Demographical factors } & Age distribution \\
& Gender \\
& Marital status \\
& Earnings \\
& Occupation \\
& Education background of the contingent \\
& employees \\
\hline \multirow{5}{*}{ Positional factors } & Type of employment (contingent or \\
& permanent) \\
& Working hours \\
& Medical aid benefits \\
\hline \multirow{5}{*}{$\begin{array}{l}\text { Environmental or organizational } \\
\text { factors }\end{array}$} & $\begin{array}{l}\text { Human capital } \\
\text { Employability of contingent employees }\end{array}$ \\
& Restructuring, downsizing \\
& Unemployment stats \\
& Globalization \\
& Location of the organization \\
& Collective bargaining \\
\hline
\end{tabular}

Source: Astarlioglu, Kazozcu \& Varnalia (2011, p. 422).

According to the TEA rate in South Africa, the gender gap has deepened depicting $61 \%$ man involvement in entrepreneurial activities, compared to $39 \%$ female involvement (GEM, 2012, p. 7). The World Bank (2011) reaffirms that there is 
approximately $50 \%$ women in developing countries actively searching for employment and South Africa included. However, the low FLFP rate is ascribed to various restrictions which prohibit women from entering the labor market and actively participating in the economy. It, however, revealed both males and females are, respectively and inversely, prejudiced from acquiring equal opportunities primarily due to qualifications and experiences. While men get to enjoy moderate work environment compared to women, Zeytinoglou (2005, p. 7) infers that did not provide any prediction for transition from contingent status to permanent contract in Spain. Other organizational factors such as business sector, industry and occupation may be necessary to explain gender preferences and stereotypes.

3.3. Marital status. Contingent jobs have been associated to involuntary working hours. Working hours of contingent employees sometime have impact on the marital status. Married contingent employees with domestic responsibilities may find hard work anomaly hours and threat of becoming jobless rises. According to Astarlioglu, Kazozcu \& Varnalia (2011, p. 423), breadwinners have high propensity to job insecurity. The link between breadwinners and job insecurity stir from fear of being laid-off or dismissed. Zeytinoglu, Denton, Davis \& Plenderleith (2009, p. 263) suggest that married contingent employees with dependent children younger than 13 are more affected by job insecurity.

Contingent employees with strong family support have lesser propensity towards job insecurity. Linz \& Semykina (2010, p. 371) reveal that married men are negative by affected by job insecurity, because they worry more than unmarried men. The study further points that both married and unmarried women are more affected by job insecurity, compared to male counterparts. According to Zeytinoglu (2005, p. 48), being divorced, widowed or separated has no effect to transition of contingent to permanent employment.

3.4. Contingent employment status. Contingent jobs pose both negative and positive feelings towards employees. The negative feelings, as a result, cause job loss or sense of powerlessness. While the positive feelings entail enjoyment of lower role and expectation, compared to permanent jobs. Contingent employees can be divided into groups: those that voluntary prefer temporary jobs (because they are parents, students, dual jobs, etc.) and individuals trapped in contingent jobs seeking permanent contract.

Green, Felstead and Burchell (2000, p. 865) suggest contingent jobs in nature, has high propensity towards job insecurity, compared to full-time jobs. According to Zeytinoglu (2005, p. 9), contingent employment is equivalent to bad jobs. In their study, Bhandari \& Heshmati (2006, p. 7) explicitly reveal that contingent employment offers low earnings, no medical aid, poor working conditions, redundancy, discrimination, minimal representation by trade unions which culminate to job dissatisfaction, distrust and job insecurity. The poor earning and work conditions of contingent employees is mainly due to cost cutting, as opposed to performance and productivity. The difference between permanent employees and contingent is vague in many organizations, because they all perform core functions of the organization (Smith, 2003). Thus, Silla, Cuyper, Gracia, Peiro \& De Witte (2009, p. 748) infer that contingent employment gives rise to job insecurity.

A distinction between permanent and contingent employment is drawn from job tenure, dismissal regulations, form of salaries, benefits, job security and working condition (Bandari \& Heshmati, 2006, p. 3). Full-time employees enjoy protection from the trade unions, collective bargaining agreements and protected towards unfair dismissal, as compared to their counterparts. According to Bandari \& Heshmati (2006, p. 3), contingent employees do not enjoy trade union protection including benefits like health, safety, welfare and social security despite their many years in service of the organizations. In light of the heterogeneity of contingent employees groups, contingent jobs tend to have less probability for one, as opposed to the other (Zeytinoglu, 2005, p. 17). It appears that it does not guarantee transition to permanent employment for both groups.

3.5. Working hours. In South Africa, the Basic Conditions of Employment Act of 1997 prescribes appropriate hours worked by contingent employees and permanent employees per week/month. According to Leibbrandt, Woolard, McEwen and Koep (2008, p. 14), in South Africa, contingent employees must work less than 35 hours per week. This determination is contrary to the view that contingent employment comprises of continuous, seasonal, cyclical and project based groups. The prescribed hours alter as an individual contingent employee gains tenure and experience increased within the organization. Zeytinoglu (2005, p. 48) makes reference to "usual" and "actual" hours worked per week, which may include involuntary, voluntary and overtime granted to specific contingent employee. The greater one works the higher the chance of earning better wage and lower job insecurity.

Contingent employees wage rates are lower than permanent employees (Posel \& Muller, 2007, p. 1). Contingent employees wage structure is built around hourly rates. So, their earning is largely reliant on the time spent at work. A lot of hours are preferable by the contingent workforce and lot of bargaining 
for it happens between managers and contingent employees. In contrast, long hours are associated with hazards of overwork, burnouts, stress, fatigue, injury and illnesses (Zeytinoglu, 2005, p. 48).

3.6. Trade union membership. Job insecurity results in unionization. Employees need protection and security against poor working conditions and dismissals (De Cuyper, De Witte, Sverke, Hellgren \& Naswall, 2014, p. 597). In case of contingent employees, unionization may pose threats for possible job prospects. Many contingent employees see their jobs as an opportunity for career advancement, therefore, cannot afford to have fears which allay opportunities for promotion (De Cuyper, De Witte, Serke, Hellgren \& Naswall, 2014, p. 586). On the other hand, contingent employees are inherently vulnerable to complain, compared to permanent employees. Unionization is the best option. The affiliation fees and administration thereof may be a limitation for contingent employees. Employers also are involved in unions' subscriptions fee collection which may increase changes of job insecurity for contingent employees. Unions' protection for contingent employees is important, yet, conditions for joining are difficult and risky.

3.7. Full-time employment status. Full-time employees are generally considered to be those scheduled to work 45 hours per week (as per Basic Condition of Employment Act of 1998). Full-time employees are likely the workers who have loyalty and sense of belonging to the company. Full-time employees are generally exposed to better employment services, compared to contingent employees. According to Jeon \& Shapiro (2006, p. 140), income differential between contingent and full-time employees was between 9.36 and $11.9 \%$ of the average employee per hour. A study by Booth (2002) reveals variance based on job satisfaction and promotions which give rise to job insecurity for continent employment. Permanent employees enjoy union representation and bargaining rights, as set out in Labor Relations Act, 1995.

3.8. Employability of contingent employees. On-thejob search for greener pastures is common amongst the workforce. Thus, the question of employability is at the core of success to the job search. Researchers have agreed that employability is an opportunity for finding alternative employment either within the organization or outside the organization (Silla, Cuyper, Gracia, Peiro \& De Witte, 2009, p. 741; Zeytinoglu, 2005, p. 57; André, 2013, p. 5).

Employability has been greatly associated with individual career trajectory, such as education, training, occupational position and experience (Smith, 2010, p. 280). Therefore, the context of lifelong and job-related learning forms basis for employability.
According to Smith (2010, p. 281), the new economy expects everyone including permanent employees to think as entrepreneurs who must avoid job insecurity by retraining and add value to the organization so that they respond to new opportunities. The global environment pressures everyone to constantly improve competencies and prepare for change. Furthermore, good work relationship between a contingent employee and the supervisor can leverage chances for re-employment or promotion of part-time employee (Meltzer, Bebbington, Brugha, Jenkins, MacManus \& Stansfeld, 2010, p. 1402).

The link between employability and job insecurity exists (Greenhalgh \& Rosenblatt, 1984, p. 31). As much as validity to the latter differ from one industry to the other (Silla, Cuyper, Gracia, Peiro \& De Witte, 2009, p. 741), career trajectory falls within lifelong learning principles.

3.9. Unemployment statistics. Card (2011, p. 9) defines unemployment as a phenomenon where people who are not working are actively and vibrantly searching for employment as counted as unemployed. Stats SA (Q2, 2013) reported staggering unemployment rate of $25.6 \%$ for the second quarter of 2013. The unemployment rates in Gauteng increased from 1.1 million in 2003 to 1.4 million in 2013 (Statistics South Africa, 2014). In 2013, unemployment rate stood at $24.3 \%$ and $-0.7 \%$ lower than in 2003. Schob (2013, p. 151) points out that high unemployment rates can drop individual's self-esteem and self-worth. High employment rates suggest that opportunities for employment or re-employment are minimal. Contingent employees hang-on to the job despite its job insecurity. Various scholars (Gali, Smets \& Wouters, 2011, p. 3; Schob, 2013, p. 153; Card, 2011, p. 11) postulate that unemployment is associated with various factors including rising salaries, labor unrest, labor markets, etc.

In a study by Card (2011, p. 9), effects of unemployment can contribute to significant health problems. Contingent employees' powerlessness and vulnerability about the jobs become severe high unemployment statistics are released jobs (Green, Felstead and Burchell, 2000, p. 867).

3.10. Contingent employees in small retail businesses. Labor Force Survey of Statistics SA (2007) cited in the SABPP 2012 report reveals that about half a million of contingent employees had been working for the same employer for more than five years. Contingent jobs were traditionally created to fill permanent employees' gaps during business cycles. Contingent employees were ignored during business slowdown and only needed when business sales improved. Statistics indicates decline of full-time jobs with benefits and contingent jobs increased (Adcorp Employment Index, May, 2014). 
Contingent jobs descriptions offered by Gallagher \& Parks (2001, p. 185) include: temporary work, seasonal work, employment agencies employees, temps, fixed-term work, part-time work, consultants, freelance, casual, and interim. It is widely accepted that no universal definition exists for contingent jobs or employees. Scholars noted some common phenomenon related contingent jobs; it is for young age, female gender, low occupational statues, low level of education and fragmentary work experience (Zeytinoglu, 2005, p. 10).

\section{Findings}

Factor analysis was carried out to reduce the number of variables into small factors (new variables). It was also used to investigate the internal consistency of factors. That is, how closely related set of items (variables in each factor) are as a group.

Table 2. Reliability of factors

\begin{tabular}{|c|c|l|c|}
\hline Section & Factor & \multicolumn{1}{|c|}{ Labels } & $\begin{array}{c}\text { Cronbach's Alpha } \\
\text { coefficient }\end{array}$ \\
\hline B1 & 1 & Job prosperity in the company & 0.79 \\
\hline \multirow{2}{*}{ B2 } & 1 & Job redundancy & 0.62 \\
\cline { 2 - 4 } & 2 & Job satisfaction about promotion & 0.67 \\
\hline
\end{tabular}

\begin{tabular}{|c|c|l|c|}
\hline \multirow{4}{*}{ B3 } & 1 & $\begin{array}{l}\text { Job satisfaction about working } \\
\text { conditions }\end{array}$ & 0.64 \\
\cline { 2 - 4 } & 2 & Job dissatisfaction & 0.58 \\
\cline { 2 - 4 } & 3 & Affiliation & 0.63 \\
\hline
\end{tabular}

Table 3. Relationship between job insecurity and retailing

\begin{tabular}{|l|l|c|c|c|}
\hline & & \multicolumn{3}{|c|}{ Nature of organization } \\
\hline & & Retailing & Other & Total \\
\hline \multirow{2}{*}{ Job prosperity in the company } & Uncertain & 58 & 11 & 69 \\
\cline { 2 - 5 } & Certain & 52 & 8 & 60 \\
\hline Total & 110 & 19 & 129 \\
\hline Chi square; $p$-value & \multicolumn{4}{|c|}{$0.174 ; 0.677$} \\
\hline \multirow{2}{*}{ Job redundancy } & Unlikely & 85 & 13 & 98 \\
\cline { 2 - 6 } & Likely & 25 & 6 & 31 \\
\hline Total & 110 & 19 & 129 \\
\hline Chi square; $p$-value & \multicolumn{4}{|c|}{$0.695 ; 0.404$} \\
\hline \multirow{2}{*}{ Job satisfaction about promotion } & Unlikely & 54 & 10 & 64 \\
\cline { 2 - 6 } & Likely & 56 & 9 & 65 \\
\hline Total & 110 & 19 & 129 \\
\hline Chi square; $p$-value & \multicolumn{4}{|c|}{$0.081 ; 0.776$} \\
\hline
\end{tabular}

The purpose of the section was to determine and compare perceptions and views of the different groups of respondents.

\subsection{Distribution of respondents by gender and by ethnicity}

\section{Gender}
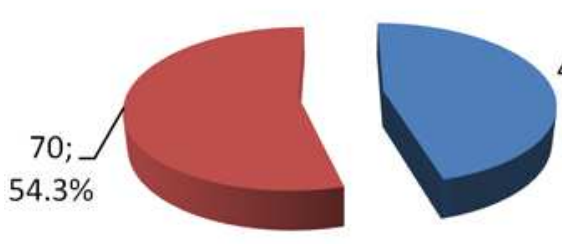

59 ;

$45.7 \%$

$13 ; 10.1 \%$

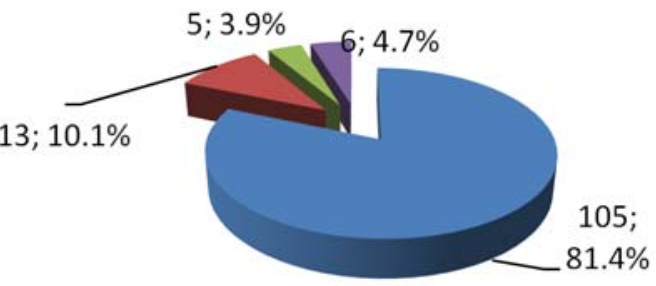

Male - Female

Out of the 129 respondents from six small retail businesses groups, 79 (54.3 per cent) composed of females and 59 (45.7 per cent) males. Dworkin, Colvin, Hatcher, Peacock (2012, p. 104) suggested not only an outward increase of female employments and job searching in labor market, but also caution about the types of jobs been taken. The results are consistent with Dworkin et al. (2012) findings. GEM (2012, p. 7) report revealed that only 39 per cent women compared to 61 per cent man participate in entrepreneurial activities in South Africa. Low level of entrepreneurial women participation can be attributed to several factors and ethnicity. It is evident from the above figure that $81.4 \%$ in majority are Africans. This is accorded to lack of education, skills and, above all, the past policies of colonializations.

\section{Ethnicity}

african $=$ Coloured $=$ Asian $=$ White

4.2. Re-visitation of hypotheses. The cross tabulation tests in a form of t-test was used to test the hypothesis that job insecurity is associated with the nature of organization.

$\mathrm{H}_{0}$ : Job insecurity is not associated with nature of organization, the alternative hypothesis.

$\mathrm{H}_{1}$ : Job insecurity is associated with nature of organization.

The findings revealed that the p-values are all less than $5 \%$, that is, 0.05 . This suggests that $\mathrm{H}_{0}$ is not rejected at 5\% significant level. So, there is no significant association between job insecurity and nature of organization.

4.3. Re-visitation of objective. The primary objective of the study is to investigate entrepreneurial skills of contingent employees in small retail businesses in Roodepoort as job security determinants. 
4.4. Empirical findings. 4.4.1. Job insecurity faced by contingent employees. Objective 1: To determine the impact job insecurity has amongst contingent employees in the small retail businesses in Roodepoort SA.

4.4.2. Job insecurity amongst contingent employees. The determinants of job insecurity to contingent employees. Entrepreneurial skills as avenue to avert contingent employees' job insecurity. The effectiveness of entrepreneurship skills in assisting contingent employees to be entrepreneurial. The questionnaire succeeded in scoping nature and impact of job insecurity amongst contingent employees in small retail businesses in Roodepoort. The threats of job loss were found to be low in comparison to job insecurity studies. Contingent employees seemed to be optimistic about job prosperities. In South Africa, educational levels vis a vis apartheid background remain important determinants for earnings. The demographical section findings showed that earnings have a relationship with age, marital status, gender and qualifications of contingent employees. The threat of losing job features is low. Contingent employees appear satisfied about working hours, work conditions and salaries are annually increased. Contingent employees exhibited some degree of appreciation and enjoyments of their jobs.

\subsubsection{Entrepreneurial skills as avenue to avert job insecurity. Objective 2: To investigate whether contingent employees have entrepreneurial skills in Roodepoort, SA.}

The strength of the relationships between the two constructs, entrepreneurial skills and job insecurity, of contingent employees acknowledging entrepreneurship as an option in this study was important. Contingent employees appear to possess high level of entrepreneurial proficiencies in Roodepoort. They seem to agree that effective entrepreneurial can be attained through education and training.

\section{Conclusions of the findings}

- The overall absence of job insecurity amongst contingent employees poses a question whether can be attributed to good working conditions in small retail businesses. An entrepreneurial drive is low amongst contingent employees.

- Potential entrepreneurs share some of the entrepreneurial skills set highlighted in the study. Individual who has all proffered entrepreneurial skills has high chance of business success.

- Potential entrepreneurs seem to share similar methods of learning entrepreneurship.

- South African institutions of learning teach wide range of entrepreneurial skills, but do not offer proper entrepreneurial skills.

\section{Limitations of the study}

The limitations of the study include the following:

- The sample size of the study was relatively limited. 503 small businesses were reported to by the Roodepoort Information and Roodepoort Chamber of Commerce \& Industry (2012). Some of small businesses in the database were not within retailing sector. Future studies need a larger sample size in order to generalize and confirm results.

- The sample frame has unknown characteristics. Unavailability of comprehensive contingent employees' database.

- Not all small retail businesses employ contingent employees. Some small retail businesses were busy (data collected in December 2014) and could not afford time to contingent employees to participate.

- Some of the small retail businesses were found to have had relocated or closed down when the questionnaire was distributed.

- Hundred and sixty five respondents were reached, but only hundred and twenty nine responses met the study requirements. Although it would be great to reach more respondents, the unavailability of contingent employees' database made it difficult.

\section{Recommendations regarding entrepreneurial skills}

The findings indicate that contingent employees need entrepreneurial skills in Roodepoort. It is clear that entrepreneurial skills fulfill multiple roles. It can pull contingent employees from job insecurity and push them towards entrepreneurship. Education and training program should be devised and rolled out for young people. The following recommendations are tabled:

- It is recommended that contingent employees should attend free education and training programs through NYDA on entrepreneurial skills. Other training providers include SEDA, SAIE, ESS Enterprise Development, Business Talk, etc.

- Contingent employees without matric should enroll with FET colleges to improve their work life and be eligible for job security or entrepreneurial education and training.

- Contingent employees with matric should enroll with Unisa and other part-time universities to improve their life.

- Contingent employees eligible to start up small businesses should register their businesses through Companies and Intellectual Property Commission (CIPC). 


\section{References}

1. Abor, J. and Quartey, P. (2010). Issues in SME Development in Ghana and South Africa, International Research Journal of Finance and Economics. Available at: http://www.eurojournals.com/irjfe_39_15.pdf. Accessed on 15 May 2014.

2. Adcorp Employment Index. (2014). Employment Quarterly: January to April 2014. Available at: http://www.adcorp.co.za/Industry/Documents/Employment\%20booklet\%20web.pdf. Accessed on 26 July 2014.

3. Astarlioglua, M., Kazozcua, S.B. \& Varnalia, R. (2011). A qualitative study of coping strategies in the context of job insecurity, Procedia Social and Behavioral Sciences, 24, pp. 421-434.

4. Bhandari, A.K. \& Heshmati. (2006). Wage Insecurity and Job Insecurity among permanent and contract workers in India: Evidence from Organized Manufacturing Industries. Available at: http://www.iza.org/publications/dps/. Accessed on 12 November 2012.

5. Card, D. (2011). Origins of the Unemployment rate: the Last Legacy of Measurement without Theory. Available at: http://davidcard.berkeley.edu/papers/origins-of-unemployment.pdf. Accessed on 28 October 2013.

6. Cooper, D.R. \& Schindler, P.S. (2014). Business Research Method. $12^{\text {th }}$ edition. New York City, NY: McGraw-Hill.

7. Dachapalli, L. \& Parumasur, S. (2012). Employee Susceptibility to Experiencing Job Insecurity, South African Journal of Economic and Sciences, 15 (1), pp. 16-30.

8. De Kok, J., Vroonhof, P., Verhoeven, W., Timmermans, N., Kwaak, T., Snijders, J. \& Westhof, F. (2011). Do SMEs create more and better jobs? Available at: www.eim.nl. Accessed on 08 August 2014.

9. De Cuyper, N., De Witte, H., Serke, M., Hellgren, J. \& Naswall, K. (2014). Felt Job Insecurity and Union Membership: The Case of Temporary Workers. Doi:10.5559/di.23.4.2. Available at: http://hrcak.srce.hr/133945. Accessed 08 January 2015.

10. Fourie, E.S. (2008). Non-Standard Workers: The South African Context, International Law and Regulation by the European Union 2008 Volume. Available at: http://www.scielo.org.za/pdf/pelj/v11n4/v11n4a05.pdf. Accessed on 07 November 2012.

11. Gallagher, D.G. \& Parks, J.M. (2001). I Pledge thee...Contingently Commitment and the Contingent Work Relationship, Human Resources Management Review, 11, pp. 108-208.

12. Gali, J., Smets, F. \& Wouters, R. (2011). Unemployment in an estimated new Keynesian Model. Working Paper 17084. Available at: http://www.nber.org/papers/w17084. Accessed on 28 October 2013.

13. Green, F., Felstead, A. \& Burchell, B. (2000). Job Insecurity and Difficulty of Regaining Employment: An Empirical Study on Unemployment Expectations, Oxford Bulletin of Economics and Statistics, Special Issue 62, pp. 0305-9049.

14. Heathfield, S. (2016). Contingent employees. Human Resource. Avalilable at: www.google.com. Accessed on 11 July 2016.

15. Herrington, M., Kew, J. \& Kew, P. (2010). Global Entrepreneurship Monitor (GEM). The UCT Centre for Innovation and Entrepreneurship.

16. Jeon, D.S. \& Shapiro, J. (2006). Downsizing and Job Insecurity, Journal of the European Economic Association, 5 (5), pp. 1043-1063.

17. Kirkwood, J. (2009). Motivational factors in a push-pull theory of entrepreneurship, Gender in Management: An International Journal, 24, pp. 346-364.

18. Leibbrandt, M., Woolard, I., McEwen, H. \& Koep, C. (2008). Employment and Inequality Outcomes in South Africa. Southern Africa Labor and Development Research Unit (SALDRU) and School of Economics, UCT. Available at: http://www.oecd.org/els/employmentpoliciesanddata/45282868.pdf. Accessed on 05 November 2012.

19. McGuinness, S. Woolen, M. \& Hahn, M. (2012). Job Insecurity and Future Labor Market Outcomes. Available at: http://ftp.iza.org/dp6764.pdf. Accessed on 11 November 2012.

20. Polivka, A.E. (1996). A profile of contingent workers. Available at: http://heinonline.org. Accessed on 23 April 2014.

21. Scarborough, N.M. \& Zimmerer, T.W. (2003). Effective Small Business Management: An Entrepreneurial Approach. $7^{\text {th }}$ edition. New Jersey: Prentice Hall Publishing.

22. Schob, R. (2013). Unemployment and Identity, CESifo Economic Studies, 59, pp. 149-180.

23. Smith, V. (2010). Enhancing employability: Human, cultural, and social capital in an era of turbulent unpredictability, Human Relations, 63, pp. 279-303.

24. Verheul, I., Thurik, R., Hessels, J. \& van der Zwan, P. (2010). Factors Influencing the Entrepreneurial Engagement of Opportunity and Necessity Entrepreneurs, Scientific Analysis of Entrepreneurship and SMEs (SCALES).

25. Zeytinoglu, I.U. (2005). Flexibility in Workplaces: Effects on Workers, Work Environment and the Unions, Geneva: IIRA/ILO. ISBN Web pdf: 92-2-116130-7. Accessed on 18 July 2012. 